\title{
ANALISIS PERILAKU PENGGUNAAN LPG PADA RUMAH TANGGA DI KOTA BOGOR
}

\author{
Behaviour Analysis of Using the Household Fuel in Bogor \\ DIAH KRISNATUTI PRANADJI ${ }^{1^{*}}$, MUHAMMAD DJEMDJEM DJAMALUDIN ${ }^{1}$, \\ NURIZA KIFTIAH ${ }^{2}$ \\ ${ }^{1}$ Staf Pengajar Departemen IImu Keluarga dan Konsumen, Fakultas Ekologi Manusia, \\ Institut Pertanian Bogor, Jalan Lingkar Kampus IPB Dramaga, Bogor 16680 \\ ${ }^{2}$ Departemen IImu Keluarga dan konsumen, Fakultas Ekologi Manusia, Institut Pertanian \\ Bogor, Kampus Dramaga, Bogor 16680
}

\begin{abstract}
The aim of this research is to analyze the behaviour in using the household fuel in Bogor. This research design used cross sectional and survey methods through the process of random sampling procedure. The total samples were 80 families. This research used descriptive analysis that contains the secondary data, literature study, and primary data. Spearman correlation and linear Regression were used to analyse the data. About $80 \%$ of respondents used only LPG as domestic fuel, $17,5 \%$ used $L P G$ fuel and other fuels, and 2,5\% used other of LPG. This result showed that $72,5 \%$ had a fairly good perception of LPG fuel, $77,5 \%$ of housewives had a good knowledge level, and 81,2\% housewives had good attitude towards LPG. In general, one tube of LPG (3kg) has been used for 7-14 days and cost average of fuel is about Rp 54.781,00/month. Housewife age and family income per capita influenced the frequency of using LPG. Trading LPG use, total family members, and housewives knowledge influenced the total $L P G$ tube use $(3 \mathrm{~kg}) / \mathrm{month}$ and expenditure for $L P G /$ month.
\end{abstract}

\section{Key words: behaviour in using the household fuel, Conversion Program from Kerosene to LPG, LPG}

\section{PENDAHULUAN}

Pada tahun 2007, pemerintah mengambil kebijakan untuk mengurangi ketergantungan masyarakat terhadap bahan bakar minyak dan pengeluaran negara dalam mensubsidinya. Hal tersebut dilakukan melalui program konversi minyak tanah bersubsidi ke Liquefied Petroleum Gas (LPG) $3 \mathrm{~kg}$. Satriya (2007) menyatakan bahwa program tersebut menargetkan konversi dari 5,2 juta kiloliter minyak tanah ke 3,5 juta ton gas yang akan dilakukan hingga tahun 2010 . Jika program konversi minyak tanah ke LPG berhasil, maka pemerintah dapat menghemat 15-20 trilyun subsidi BBM per tahun (Departemen ESDM 2007). Adapun tujuan dari kebijakan ini ialah dalam rangka: (a) melakukan diversifikasi pasokan energi untuk mengurangi ketergantungan terhadap BBM; (b) melakukan efisiensi anggaran pemerintah karena penggunaan LPG lebih efisien dan subsidinya relatif lebih kecil daripada subsidi minyak tanah; (c) menyediakan bahan bakar yang praktis, bersih, serta efisien untuk rumah tangga dan usaha mikro (Anonim 2007).

Program konversi minyak tanah ke LPG sudah berjalan lebih dari dua tahun yang diawali uji coba penggunaan pada bulan Agustus dan Desember 2006. Program ini melibatkan beberapa instansi pemerintah dan konsultan independen. Metode sosialisasi yang telah dilakukan antara lain melalui penyuluhan dan iklan layanan masyarakat di radio maupun televisi. Pesan yang disampaikan yaitu "LPG lebih mudah, hemat, aman, bersih, ramah lingkungan, dan praktis". Dari uji coba penggunaan disimpulkan bahwa program pengalihan akan mendapat dukungan dari masyarakat. Menurut penelitian Amiruddin (2009) seseorang lebih suka menggunakan LPG daripada minyak tanah dengan alasan utama yaitu cepat, hemat, praktis, dan bersih. Selain itu, telah dilakukan penelitian mengenai aspek sosial budaya program konversi BBM mengenai kesiapan 
dan kesediaan berpartisipasi dalam program tersebut.

Hasil uji coba tersebut tidak sejalan dengan fakta yang terjadi di masyarakat ketika program dijalankan. Pada pelaksanaannya program konversi minyak tanah ke LPG yang dilakukan di beberapa wilayah tidak mudah mengubah perilaku konsumsi energi bahan bakar rumah tangga dari minyak tanah ke LPG. Tingkat penerimaan dan partisipasi keluarga di berbagai wilayah berbeda-beda, dan tingkat partisipasi paling rendah yang dilaporkan adalah $30 \%$. Bahkan diduga terdapat sebagian keluarga yang semula mencoba beralih dari minyak tanah ke LPG, kembali menggunakan bahan bakar minyak (Amiruddin 2009).

Permasalahan pengetahuan dan teknis penggunaan LPG terlihat dari minimnya pemahaman masyarakat mengenai penggunaan, fungsi, prosedur pengamanan kompor gas jika terjadi kebocoran dan cara penanganan kerusakan lainnya (Aziz 2008). Ketidakpahaman dan ketidaksiapan masyarakat dari segi teknis penggunaan kompor gas dapat memberikan dampak trauma bagi masyarakat. Secara psikologis, sebagian besar masyarakat mengalami ketakutan dalam menggunakan kompor gas, karena banyaknya kasus kompor gas yang meledak sehingga merasa lebih aman menggunakan bahan bakar lain seperti minyak tanah dan kayu bakar. Selain itu, permasalahan ekonomi yang muncul dalam penerapan konversi minyak tanah ke gas ini ialah pemanfaatan gas yang membutuhkan dana yang lebih besar daripada penggunaan minyak tanah. Pembelian isi ulang gas dalam bentuk tabung mengharuskan masyarakat untuk menyediakan uang yang lebih banyak dibandingkan dengan pembelian minyak tanah (Aziz 2008).

Penelitian ini bertujuan untuk: (1) mengidentifikasi karakteristik sosial ekonomi rumah tangga; (2) mengidentifikasi keterjangkauan media informasi responden; (3) mengidentifikasi persepsi, pengetahuan, dan sikap responden terhadap LPG; (4) mengidentifikasi perilaku rumah tangga terhadap penggunaan LPG; dan (5) menganalisis hubungan dan pengaruh karakteristik sosial ekonomi rumah tangga, keterjangkauan media informasi, persepsi, pengetahuan, dan sikap responden terhadap perilaku penggunaan LPG pada rumah tangga.

\section{METODE}

Desain, Lokasi, dan Waktu

Desain penelitian ini adalah cross sectional study dengan metode survei. Pengambilan data dilakukan selama tiga bulan, yakni pada bulan April-Juni 2009 di Kecamatan Bogor Utara dan Kecamatan Bogor Timur, Kota Bogor.

\section{Metode Penarikan Contoh}

Populasi penelitian ini adalah keluarga perkotaan di Kota Bogor. Contoh dalam penelitian ini adalah 80 rumah tangga keluarga berdomisili di wilayah Kecamatan Bogor Utara dan Kecamatan Bogor Timur. Dari masing-masing kecamatan kemudian dipilih dua kelurahan secara acak, sehingga terpilih Kelurahan Cibuluh dan Kelurahan Ciluar pada Kecamatan Bogor Utara; Kelurahan Sukasari dan Kelurahan Sindangrasa pada Kecamatan Bogor Timur. Pada setiap kelurahan dipilih dua RW, kemudian dipilih dua RT secara acak. Adapun yang menjadi responden dalam penelitian ini adalah ibu rumah tangga dari keluarga-keluarga yang diteliti dan diasumsikan jawaban responden mencerminkan respon keluarga. Dari masing-masing RT tersebut dipilih lima responden secara acak dengan ketentuan responden merupakan ibu rumah tangga dan bersedia untuk diwawancara. Melalui teknik ini kemudian diperoleh sebanyak 80 contoh. Namun, pengukuran analisis regresi perilaku penggunaan bahan bakar rumah tangga pada penelitian ini hanya dilakukan pada 78 contoh karena dua orang contoh tidak mengunakan LPG.

\section{Teknik Pengumpulan Data}

Data yang dikumpulkan pada penelitian ini meliputi data primer dan data sekunder. Data primer meliputi karakteristik rumah tangga (usia, pendidikan, pekerjaan, besar keluarga, dan pendapatan per kapita); riwayat penggunaan bahan bakar; keterjangkauan sumber media informasi (sumber dan jenis informasi, waktu mengakses informasi, serta sikap terhadap iklan); persepsi, pengetahuan, dan sikap responden terhadap bahan bakar rumah tangga; dan perilaku rumah tangga terhadap penggunaan bahan bakar rumah tangga (bahan bakar yang digunakan, jenis dan ukuran, tempat pembelian, frekuensi penggunaan bahan bakar, jumlah penggunaan bahan bakar rumah tangga/bulan, dan pengeluaran untuk bahan bakar rumah tangga/bulan). Data 
sekunder diperoleh dari instansi terkait meliputi gambaran umum, potensi, data monografi, dan data penduduk. Metode pengambilan data primer dilakukan secara survei melalui wawancara dengan menggunakan kuesioner.

\section{Pengolahan dan Analisis Data}

Data yang telah terkumpul diolah dengan menggunakan program Microsoft Excel dan SPSS for windows. Analisis data penelitian ini dilakukan dengan: (1) Uji Korelasi Pearson. Uji ini digunakan untuk melihat hubungan antara variabel-variabel yang diteliti yaitu karakteristik sosial ekonomi; keterjangkauan media informasi; pengetahuan, persepsi, dan sikap terhadap LPG; perilaku rumah tangga terhadap penggunaan LPG; (2) Uji Regresi Linier berganda. Uji ini digunakan untuk mengetahui pengaruh antara karakteristik sosial ekonomi, keterjagkauan media informasi, pengetahuan, persepsi, sikap terhadap bahan bakar rumah tangga dengan perilaku penggunaan bahan bakar. Pada uji regresi linier berganda hanya penggunaan LPG yang di analisis.

\section{HASIL DAN PEMBAHASAN}

\section{Karakteristik Rumah Tangga}

Usia. Usia suami berkisar antara 26 hingga 70 tahun dengan rata-rata usia suami secara keseluruhan adalah 43,6 tahun. Sebanyak $54 \%$ diantaranya berusia $41-60$ tahun, sedangkan yang berusia di bawah 41 tahun sebanyak $39,2 \%$. Usia istri berkisar antara 23 sampai 70 tahun dengan rata-rata 38,8 tahun. Persentase terbesar istri termasuk dalam kategori dewasa muda $(62,5 \%)$ (Tabel 1).

Pendidikan. Tingkat pendidikan suami tersebar dari tidak sekolah, tidak tamat SD, tamat SD, tamat SMP, tamat SMA, dan tamat Perguruan Tinggi. Tidak ada ibu rumah tangga yang tingkat pendidikannya sampai dengan perguruan tinggi atau akademi. Persentase terbesar tingkat pendidikan suami ialah tamat SD $(35,1 \%)$. Sama halnya dengan pendidikan suami, pendidikan sepertiga istri juga tergolong masih rendah. Persentase terbesar tingkat pendidikan istri secara umum ialah tamat SD $(41,2 \%)$ (Tabel 1).

Pekerjaan. Pekerjaan utama suami adalah sebagai buruh $(37,8 \%)$. Hanya $16,3 \%$ istri bekerja umumnya sebagai pedagang (Tabel 1). Sebagian kecil keluarga contoh
(15\%) memiliki usaha yang menggunakan LPG (Tabel 2).

Tabel 1. Karakteristik keluarga berdasarkan usia, pendidikan, dan pekerjaan

\begin{tabular}{|c|c|c|c|c|c|}
\hline \multirow{2}{*}{ No } & \multirow{2}{*}{ Kategori } & \multicolumn{2}{|c|}{ Suami } & \multicolumn{2}{|c|}{ Istri } \\
\hline & & $\mathbf{n}$ & $\%$ & $\mathbf{n}$ & $\%$ \\
\hline & Usia & & & & \\
\hline 1 & Dewasa awal (18-40 th) & 29 & 39,2 & 50 & 62,5 \\
\hline 2 & $\begin{array}{l}\text { Dewasa menengah } \\
\text { (41- } 60 \text { th) }\end{array}$ & 40 & 54,0 & 27 & 33,7 \\
\hline \multirow[t]{2}{*}{3} & Dewasa akhir ( $\geq 60$ th) & 5 & 6,8 & 3 & 3,8 \\
\hline & Total & 74 & 100,0 & 80 & 100,0 \\
\hline & Pendidikan & & & & \\
\hline 1 & Tidak sekolah & 3 & 4,1 & 2 & 2,5 \\
\hline 2 & Tidak Tamat SD & 8 & 10,8 & 15 & 18,8 \\
\hline 3 & Tamat SD & 26 & 35,1 & 33 & 41,2 \\
\hline 4 & Tamat SMP & 14 & 18,9 & 20 & 25,0 \\
\hline 5 & Tamat SMA & 22 & 29,7 & 10 & 12,5 \\
\hline \multirow[t]{2}{*}{6} & Tamat Perguruan Tinggi & 1 & 1,4 & 0 & 0,0 \\
\hline & Total & 74 & 100,0 & 80 & 100,0 \\
\hline 1 & $\begin{array}{l}\text { Pekerjaan } \\
\text { Tidak bekerja/lbu rumah } \\
\text { tangga }\end{array}$ & 0 & 0,0 & 51 & 63,7 \\
\hline 2 & Pensiunan & 4 & 5,4 & 2 & 2,5 \\
\hline 3 & Buruh & 28 & 37,8 & 4 & 5,0 \\
\hline 4 & Supir/Ojek & 8 & 10,8 & 0 & 0,0 \\
\hline 5 & Pedagang & 7 & 9,5 & 20 & 25,0 \\
\hline 6 & $\begin{array}{l}\text { Karyawan/Pegawai } \\
\text { swasta }\end{array}$ & 17 & 23,0 & 0 & 0,0 \\
\hline 7 & PNS & 4 & 5,4 & 0 & 0,0 \\
\hline 8 & Wiraswasta & 6 & 8,1 & 0 & 0,0 \\
\hline \multirow[t]{2}{*}{9} & PRT/Pengasuh & 0 & 0,0 & 3 & 3,8 \\
\hline & Total & 74 & 100,0 & 80 & 100,0 \\
\hline
\end{tabular}

Tabel 2. Karakteristik rumah tangga berdasarkan besar keluarga, pendapatan perkapita dan kepemilikan usaha yang menggunakan LPG

\begin{tabular}{|c|c|c|c|}
\hline \multirow{2}{*}{ No } & \multirow{2}{*}{ Kategori } & \multicolumn{2}{|c|}{ Total } \\
\hline & & $\mathrm{n}$ & $\%$ \\
\hline & Besar keluarga & & \\
\hline 1 & Keluarga kecil (s4orang) & 47 & 58,7 \\
\hline 2 & Keluarga sedang (5- 6 orang) & 25 & 31,3 \\
\hline \multirow[t]{3}{*}{3} & Keluarga besar ( $\geq 7$ orang) & 8 & 10,0 \\
\hline & Total & 80 & 100,0 \\
\hline & Pendapatan/kapita/bulan & & \\
\hline 1 & $<\operatorname{Rp} 203.751,00$ & 19 & 23,8 \\
\hline \multirow[t]{3}{*}{2} & > Rp 203.751,00 & 51 & 76,2 \\
\hline & Total & 80 & 100,0 \\
\hline & $\begin{array}{l}\text { Kepemilikan usaha yang } \\
\text { menggunakan LPG }\end{array}$ & & \\
\hline 1 & Memiliki usaha & 12 & 15,0 \\
\hline \multirow[t]{2}{*}{2} & Tidak memiliki & 68 & 85,0 \\
\hline & Total & 80 & 100,0 \\
\hline
\end{tabular}

Tipe dan Besar Keluarga. Anggota keluarga contoh berkisar antara 2-9 orang dengan rata-rata jumlah anggota keluarga 4,4 orang. Persentase terbesar keluarga contoh $(58,7 \%)$ termasuk dalam kategori keluarga kecil (Tabel 2).

Pendapatan. Pendapatan per kapita per bulan keluarga contoh berkisar antara Rp 92.857,14 - Rp 1.333.333,00 dengan 
rata-rata pendapatan per kapita per bulan berkisar Rp 341.838,14. Berdasarkan BPS 2009, garis kemiskinan perkotaan di propinsi Jawa Barat sebesar Rp 203.751,00 sehingga dapat digolongkan hanya sebagian kecil $(23,8 \%)$ keluarga contoh termasuk keluarga miskin (Tabel 2).

\section{Riwayat Penggunaan Bahan Bakar}

Sebagian besar ibu rumah tangga (80\%) menggunakan hanya LPG sebagai bahan bakar rumah tangga, $17,5 \%$ menggunakan LPG dan bahan bakar lain sebagai bahan bakar rumah tangga dan sebagian kecil $(2,5 \%)$ menggunakan bahan bakar selain LPG sebagai bahan bakar rumah tangga.

Pengguna minyak tanah sebelum konversi sebanyak $67,5 \%$ menurun menjadi $1,2 \%$ sebaliknya pengguna LPG sebelum program konversi sebanyak $1,2 \%$ naik menjadi $80 \%$. Jumlah keluarga contoh pengguna kayu bakar tetap $(1,2 \%)$ sebelum dan sesudah program konversi. Terjadi penurunan jumlah keluarga contoh yang menggunakan kombinasi bahan bakar (minyak tanah, kayu bakar, dan LPG) dari sebelum dan sesudah program konversi minyak tanah ke LPG sebanyak $12,5 \%$. Hal ini berkaitan dengan semakin langka dan mahal harga minyak tanah bersubsidi.

\section{Media Informasi}

Informasi diperoleh dari berbagai sumber termasuk teman, anggota keluarga dan media massa. Engel et al. (1994) membagi sumber informasi ke dalam sumber informasi personal (teman dan keluarga) dan impersonal (media massa dan informasi dalam toko). Informasi mengenai konversi dan penggunaan LPG yang diterima keluarga contoh berasal dari penyuluh, sales/toko, saudara, tetangga, tempat bekerja, dan iklan. Persentase terbesar sumber informasi keluarga contoh berasal dari penyuluh $(80,6 \%)$. Hal ini karena lebih dari separuh keluarga contoh $(68,7 \%)$ menggunakan LPG setelah program konversi BBM. Sebagian besar keluarga contoh $(83,7 \%)$ hanya mendapatkan informasi dari satu sumber. Secara keseluruhan rata-rata jumlah sumber informasi yang dimiliki keluarga contoh sebanyak 1,2 atau kurang dari dua sumber.

Kepemilikan media informasi dapat memudahkan keluarga contoh dalam mengakses informasi terutama mengenai konversi BBM. Hal ini juga berkaitan dengan waktu dan acara serta kebiasan apa yang dilakukan keluarga contoh ketika menonton TV, mengingat informasi tentang konversi BBM biasanya disajikan dalam bentuk berita dan iklan layanan masyarakat.

Persentase terbesar acara yang disaksikan ibu rumah tangga ialah sinetron $(47,4 \%)$ sedangkan berita hanya disaksikan oleh $6,8 \%$ ibu rumah tangga. Informasi mengenai konversi BBM dan penggunaannya dapat diperoleh dari media massa berupa berita dan iklan layanan masyarakat. Lebih dari setengah ibu rumah tangga $(66,6 \%)$ pernah melihat iklan baik itu iklan komersil maupun layanan masyarakat di televisi.

Iklan adalah salah bentuk komunikasi pemasaran untuk membentuk persepsi positif konsumen terhadap suatu produk (Sumarwan 2006). Persepsi yang terbangun diharapkan meningkatkan sikap positif konsumen sehingga konsumen percaya dan mau membeli serta menggunakan produk tersebut. Akan tetapi, lebih dari separuh ibu rumah tangga $(53,7 \%)$ memiliki sikap mengganti saluran ketika iklan sehingga ada peluang ketika iklan layanan masyarakat ditayangkan tidak disaksikan, sedangkan yang tetap menyimak iklan hanya $22,5 \%$. Keluarga contoh yang memperoleh informasi mengenai konversi BBM dan cara penggunaan LPG dari iklan hanya 6,4\%.

Sebagian besar ibu rumah tangga $(87,5 \%)$ menyatakan media massa (televisi, radio, dan surat kabar) tidak mempengaruhi keputusan untuk menggunakan LPG tetapi lebih karena kelangkaan dan program yang dicanangkan oleh pemerintah. Sebagian besar ibu rumah tangga memutuskan menggunakan LPG karena himbauan dari pemerintah $(67,5 \%)$ dan mulai ditariknya minyak bersubsidi. Ibu rumah tangga yang memutuskan menggunakan LPG karena kesadaran/keinginan pribadi sebanyak $21,2 \%$ sedangkan sisanya $(11,3 \%)$ karena anjuran saudara.

\section{Persepsi, Pengetahuan dan Sikap terhadap LPG}

Persepsi terhadap LPG. Persepsi merupakan sebuah proses yang aktif dari dalam diri manusia dalam memilih, mengelompokkan, dan memberikan makna pada informasi yang diterimanya (Kotler \& Keller 2006). Persepsi terhadap LPG akan mempengaruhi sikap dan penerimaan ibu rumah tangga terhadap LPG. Seluruh ibu rumah tangga $(100 \%)$ memiliki persepsi 
bahwa memasak menggunakan LPG lebih cepat daripada menggunakan bahan bakar lainnya (kayu bakar atau minyak tanah) baik untuk memasak air, nasi, sayur, maupun lauk. Hal ini sesuai dengan hasil penelitian Latifah (2010) yang menyatakan bahwa $100 \%$ ibu rumah tangga di Kecamatan Bogor Barat dan Bogor Selatan memiliki persepsi terhadap waktu penggunaan LPG lebih cepat dibandingkan bahan bakar lain (minyak tanah). Hal ini sesuai dengan kelebihan yang dimiliki LPG dalam mengefisienkan waktu memasak.

Responden memiliki persepsi yang berbeda mengenai rasa makanan yang dimasak dengan menggunakan LPG. Secara keseluruhan responden berpendapat bahwa memasak menggunakan LPG tidak merubah rasa makanan (air, nasi, sayur, dan lauk). Sebagian besar responden menyatakan kurang setuju bahwa rasa makanan yang dimasak menggunakan LPG lebih enak dibandingkan dengan menggunakan bahan bakar lain (kayu bakar atau minyak tanah).

Sebagian besar ibu rumah tangga menyetujui bahwa memasak dengan LPG menghemat pengeluaran $(88,7 \%)$, harga LPG tidak akan naik karena stoknya banyak $(86,2 \%)$. Hal ini sesuai dengan keunggulan yang dimiliki LPG yaitu dapat menghemat pengeluaran untuk bahan bakar. Akan tetapi masih merasa khawatir terhadap suara yang ditimbulkan oleh kompor gas $(68,7 \%)$ dan sebagian kecil responden merasa tabung gas mudah meledak dan kompor gas mudah rusak (15\%). Hal ini sesuai dengan hasil penelitian Amiruddin (2009) yang menyatakan bahwa, persepsi negatif terhadap LPG berkaitan dengan kepentingan program dan keamanan LPG.

Proporsi terbesar ibu rumah tangga $(72,5 \%)$ termasuk ke dalam kategori persepsi yang cukup baik. Hal ini sejalan dengan hasil penelitian Latifah (2010) yang menyatakan bahwa persepsi yang dimiliki ibu rumah tangga sudah cukup baik karena diduga LPG telah memiliki karakteristik produk yang diinginkan oleh masyarakat. Pertama, LPG merupakan bahan bakar yang dibutuhkan oleh masyarakat. Kedua, LPG memiliki beberapa kelebihan dibandingkan dengan minyak tanah yaitu lebih hemat, praktis, ramah lingkungan, dan sebagainya. Ketiga, kemungkinan tidak ada alternatif bahan bakar lain yang tersedia sehingga masyarakat menggunakan LPG. Namun masih terdapat hampir seperempat responden $(21,2 \%)$ yang memiliki persepsi kurang baik terhadap LPG. Menurut Latifah (2010) harga LPG yang masih kurang terjangkau oleh masyarakat miskin serta sosialisasi program yang belum maksimal diduga sebagai faktor yang cukup mempengaruhi persepsi terhadap LPG.

Pengetahuan tentang LPG. Pengetahuan adalah informasi yang disimpan dalam ingatan yang menjadi penentu utama perilaku konsumen (Engel et al. 1994). Hal ini sejalan dengan pendapat Sumarwan (2004) bahwa pengetahuan akan mempengaruhi pembelian. Pengetahuan dapat diperoleh dari pendidikan formal maupun informal. Selain itu, masyarakat dapat mengetahui informasi tentang bahan bakar khususnya LPG melalui media komunikasi yaitu media cetak (koran, tabloid, dan majalah), media elektronik (televisi dan radio), penyuluhan, referensi orang lain, maupun pengalaman pribadi.

Pengetahuan produk yang dimiliki ibu rumah tangga sudah cukup baik diantaranya pengetahuan akan karakteristik dan manfaat produk. Pengetahuan akan mempengaruhi perilaku yang dilakukan oleh rumah tangga. Proporsi terbesar responden (77,5\%) termasuk dalam kategori memiliki pengetahuan yang baik mengenai LPG.

Sikap terhadap LPG. Sumarwan (2004) mendefinisikan sikap sebagai ungkapan konsumen tentang suatu objek apakah disukai/tidak dan menggambarkan kepercayaan konsumen terhadap berbagai atribut dan manfaat dari objek tersebut. Secara umum sebagian besar responden $(81,2 \%)$ telah memiliki sikap yang baik terhadap bahan bakar LPG. Hal ini diduga karena persepsi dan pengetahuan yang dimiliki responden sudah cukup baik sehingga sikap responden terhadap LPG pun baik.

\section{Perilaku Penggunaan Bahan Bakar Rumah Tangga \\ Jenis Bahan Bakar yang Digunakan} dan Tempat Pembelian. Sebagian besar keluarga contoh menggunakan LPG sebagai bahan bakar rumah tangga sebesar $80 \%$ sedangkan 2,5\% keluarga contoh menggunakan bahan bakar selain LPG dan sisanya $17,5 \%$ menggunakan LPG dan juga bahan bakar lain. Bentuk dan jenis tabung LPG yang dimiliki oleh keluarga contoh pada umumnya berukuran $3 \mathrm{~kg}$ dan hanya ada empat keluarga contoh yang memiliki tabung LPG ukuran $12 \mathrm{~kg}$. Hal ini karena sebagian besar responden menggunakan LPG setelah 
mendapatkan pembagian LPG dari pemerintah melalui program konversi minyak tanah ke LPG. Sebagian besar $(78,7 \%)$ keluarga contoh yang menggunakan LPG sebagai bahan bakar memiliki tabung LPG sebanyak satu buah.

Pembelian LPG biasanya dilakukan di berbagai tempat yaitu warung, supermarket, agen atau pun pom bensin. Seluruh ibu rumah tangga (100\%) membeli LPG di warung sekitar rumah. Lebih dari tiga perempat ibu rumah tangga $(82,1 \%)$ akan mencari LPG ke tempat lain jika persediaan LPG di warung langganan tidak ada. Hal ini dilakukan karena akses memperoleh LPG sudah mudah, karena banyak warung yang menjual LPG. Beberapa responden (11,5\%) menyatakan akan tetap menunggu persediaan LPG di tempat pembelian, karena tempat pembelian biasanya/langganan selama ini belum pernah mengalami kehabisan persediaan LPG. Sebagian kecil responden $(6,4 \%)$ memilih menggunakan bahan bakar lain ketika tidak tersedia LPG di tempat pembelian. Ibu rumah tangga yang menggunakan minyak tanah sebagai bahan bakar membelinya di warung yang memiliki persediaan minyak. Sementara itu, ibu rumah tangga yang menggunakan kayu bakar memperolehnya dari kayu yang tersedia di lingkungan sekitar rumah.

Frekuensi Penggunaan Bahan Bakar Rumah Tangga. Hasil penelitian menunjukkan bahwa responden sering menggunakan LPG untuk memasak air $(77,5 \%)$, nasi $(38,7 \%)$, sayur $(91,2 \%)$, dan lauk $(92,5 \%)$. Lebih dari separuh responden $(53,7 \%)$ menggunakan peralatan rumah tangga berbentuk elektronik untuk memasak nasi. Hal ini diduga karena untuk memasak nasi dianggap lebih praktis menggunakan alat elektronik (rice cooker atau magic jar).

Jumlah Penggunaan Tabung LPG 3 Kg. Hasil penelitian menunjukkan bahwa keluarga contoh yang menggunakan LPG memiliki waktu habis penggunaan satu tabung LPG $3 \mathrm{~kg}$ yang cukup bervariasi. Rata-rata tabung LPG $3 \mathrm{~kg}$ digunakan oleh keluarga contoh selama 11,6 hari. Persentase terbesar keluarga contoh $(41,2 \%)$ dalam menggunakan tabung LPG $3 \mathrm{~kg}$ habis dalam waktu kurang atau sama dengan 7 hari. Hal ini sesuai dengan hasil uji coba program konversi di Kelurahan Cempaka baru bahwa $88 \%$ responden menggunakan LPG $3 \mathrm{~kg}$ diatas 7 hari (asumsi awal 1 tabung LPG 3 $\mathrm{kg}=5$ hari) (Anonim 2007).
Pada keluarga contoh yang menggunakan LPG, banyaknya LPG yang digunakan cukup bervariasi, mulai dari 1 hingga 15 tabung LPG $3 \mathrm{~kg}$ per bulan dengan rata-rata pemakaian 3,8 tabung per bulan. Persentase penggunaan LPG terbanyak ialah kurang atau sama dengan 4 tabung per bulan. Dilihat dari jumlah anggota keluarga, sebagian besar keluarga contoh yang menggunakan LPG termasuk kedalam keluarga kecil sehingga penggunaan LPG setiap bulan dapat 1-4 tabung. Jumlah tabung yang digunakan oleh keluarga tergantung pada jumlah anggota keluarga dan kebiasaan penggunaan yaitu digunakan seperlunya saja.

Pengeluaran untuk Bahan Bakar Rumah Tangga. Pengeluaran yang dilakukan keluarga contoh untuk bahan bakar rumah tangga berkisar antara Rp 15.000,00 Rp 225.000,00 per bulan dengan rata-rata Rp 54.781,00 per bulan. Proporsi terbesar keluarga contoh $(43,7 \%)$ berada pada kisaran $\leq$ Rp 30.000,00. Sementara itu, pada kelompok pengguna LPG dan bahan bakar lain proporsi terbesar (35\%) mengeluarkan pengeluaran untuk bahan bakar/bulan sebesar Rp 31.000,00 - Rp 60.000,00. Ratarata pengeluaran yang dikeluarkan keluarga contoh pengguna LPG (Rp 52.867,19) lebih sedikit dibandingkan dengan pengguna LPG dan bahan bakar lain (Rp 61.266,67). Keluarga contoh yang tidak menggunakan LPG memiliki pengeluaran untuk bahan bakar antara Rp 61.000,00 - Rp 90.000,00 bagi pengguna minyak tanah, sedangkan pengguna kayu bakar menge-luarkan pengeluaran $\leq \operatorname{Rp} 30.000,00$.

Keluarga contoh yang menggunakan LPG menyatakan bahwa alasan menggunakan LPG karena memiliki keunggulan diantaranya yaitu hemat, praktis, bersih, efisien, cepat, murah, tidak bau, tidak ada asap sehingga aman untuk kesehatan, dan mudah dalam penggunaan dan perawatan. Selain itu penggunaan LPG dilakukan karena tidak ada minyak tanah bersubsidi dipasaran.

Hasil penelitian menunjukkan bahwa lebih dari tiga perempat ibu rumah tangga $(80 \%)$ akan berpindah ke bahan bakar lain jika ada bahan bakar yang dirasa lebih aman. Ibu rumah tangga yang tetap bertahan pada bahan bakar yang digunakan walaupun ada bahan bakar yang dirasa lebih aman memiliki alasan bahwa memerlukan waktu untuk beradaptasi kembali dengan yang baru. Berbeda dengan aspek keamanan, hanya $47,5 \%$ ibu rumah tangga akan 
berpindah kepada bahan bakar lain jika ada bahan bakar yang lebih murah sedangkan sisanya $(52,5 \%)$ tidak akan berpindah jika ada bahan bakar yang lebih murah. Alasan ibu rumah tangga tidak berpindah karena selain harus beradaptasi kembali kepada bahan bakar yang baru, peralatan yang digunakan pun akan berubah dan akan berdampak pada biaya tambahan lainnya. Dari hasil penelitian diperoleh bahwa ibu rumah tangga cenderung lebih memilih keamanan dari pada harga jika harus mengganti dengan bahan bakar lainnya. Penyesuaian diri dan peralatan yang harus diganti jika mengganti bahan bakar menjadi bahan pertimbangan ibu rumah tangga untuk mengganti bahan bakar.

\section{Hubungan antar Variabel}

Sikap ibu rumah tangga terhadap LPG. Ibu rumah tangga yang memiliki pendidikan sedang tidak mempunyai sikap yang negatif/kurang baik terhadap bahan bakar. Sikap positif semakin meningkat dengan meningkatnya tingkat pendidikan yaitu dari $78 \%$ menjadi $86,7 \%$. Hasil uji korelasi Pearson menunjukkan adanya hubungan yang positif antara pendidikan ibu rumah tangga dengan sikap terhadap bahan bakar LPG $\left(p=0,007^{*} ; \quad r=0,297\right)$. Hal ini berarti semakin tinggi pendidikan seseorang maka sikap terhadap bahan bakar semakin positif/baik. Hal ini sesuai dengan penelitian yang dilakukan Latifah (2010) bahwa semakin lama ibu rumah tangga bersekolah, maka sikap ibu rumah tangga terhadap LPG semakin baik.

Berdasarkan hasil uji korelasi Pearson pengetahuan memiliki hubungan yang positif terhadap sikap responden $\left(p=0,000^{* *}\right.$; $r=0,614)$. Dengan kata lain semakin baik pengetahuan seseorang mengenai bahan bakar LPG maka semakin baik sikap responden terhadap bahan bakar LPG. Seseorang yang memiliki pengetahuan yang baik biasanya lebih mudah menerima keberadaan sesuatu yang asing atau tidak biasa dibandingkan orang yang memiliki pengetahuan kurang baik. Hal ini sesuai dengan pernyataan Azwar (1988) dalam Okturna (2004) yang menyatakan bahwa institusi atau lembaga pendidikan merupakan salah satu faktor yang mempengaruhi pembentukan sikap.

Sikap merupakan fungsi dari pengetahuan (Ilyas \& Sudarnika 2002). Sikap individu terhadap suatu objek menyangkut aspek pendapat, keyakinan, serta penilaian, dan ketiga aspek ini berhubungan dengan pengetahuan/pengertian individu terhadap objek tersebut. Pengetahuan terhadap fakta yang positif akan menumbuhkan sikap positif terhadap objek, dan sebaliknya pengetahuan fakta negatif dari objek akan cenderung menimbulkan sikap negatif terhadap objek yang bersangkutan.

\section{Perilaku Penggunaan LPG \\ Waktu habis satu tabung LPG $3 \mathrm{~kg}$ dan jumlah penggunaan tabung} LPG/bulan. Berdasarkan hasil uji korelasi Pearson, besar keluarga memiliki hubungan dengan waktu habis satu tabung LPG $3 \mathrm{~kg}$ $\left(p=0,000^{*} ; r=-0,392\right)$ dan jumlah tabung yang digunakan $\left(p=0,000^{*} ; r=-0,613\right)$. Hal ini berarti bahwa semakin besar keluarga contoh, maka waktu habis satu tabung LPG $3 \mathrm{~kg}$ semakin cepat dan jumlah tabung yang digunakan semakin banyak.

Besar keluarga menentukan jumlah konsumsi yang dibutuhkan suatu keluarga. Keluarga yang memiliki jumlah anggota lebih banyak akan membutuhkan makanan yang lebih banyak dibandingkan dengan keluarga yang memiliki anggota sedikit. Hal ini akan mempengaruhi jumlah energi yang digunakan. Pada keluarga kecil persentase terbesar penggunaan LPG antara $7-14$ hari $(38,3 \%)$, sedangkan pada keluarga sedang persentase terbesar pada penggunaan kurang dari/sama dengan 7 hari $(48 \%)$. Diantara responden ada yang dapat menggunakan satu tabung LPG ukuran $3 \mathrm{~kg}$ hingga lebih atau sama dengan 21 hari yaitu pada keluarga kecil $(8,5 \%)$ dan pada keluarga sedang (4\%). Pada keluarga besar persentase terbesar penggunaan LPG hanya sampai kurang dari/sama dengan 7 hari $(75 \%)$. Semakin besar keluarga maka semakin banyak pula tabung LPG yang dipergunakan tiap bulan. Pada keluarga kecil persentase terbesar keluarga contoh mengggunakan kurang atau sama dengan 4 tabung/bulan sedangkan pada keluarga besar 4-10 tabung/bulan.

Persentase terbesar $(83,3 \%)$ keluarga contoh yang memiliki usaha yang menggunakan LPG waktu habis tabung LPG $3 \mathrm{~kg}$ selama $\leq 7$ hari. Persentase terbesar $(41,2 \%)$ keluarga contoh yang tidak memiliki usaha yang menggunakan LPG waktu habis tabung LPG $3 \mathrm{~kg}$ selama 7-14 hari. Hasil uji korelasi Pearson menunjukkan bahwa ada hubungan antara kepemilikan usaha yang menggunakan LPG ( $\left.p=0,009^{*} ; \quad r=-0,292\right)$ terhadap waktu habis satu tabung LPG $3 \mathrm{~kg}$. 
Hal ini berarti keluarga contoh yang memiliki usaha menggunakan LPG memiliki waktu habis satu buah tabung LPG $3 \mathrm{~kg}$ lebih cepat dibandingkan dengan responden yang tidak memiliki usaha menggunakan LPG.

Persentase terbesar keluarga contoh $(72,1 \%)$ menggunakan tabung LPG kurang atau sama dengan 4 tabung setiap bulan. Pada keluarga contoh yang memilki usaha menggunakan LPG persentase terbesar menggunakan LPG sebanyak 4-10 tabung setiap bulan. Hasil uji korelasi Pearson menunjukkan ada hubungan antara kepemilikan usaha yang menggunakan LPG terhadap jumlah tabung LPG $3 \mathrm{~kg}$ yang digunakan per bulan ( $\left.p=0,000^{* *} ; r=0,616\right)$. Hal ini berarti keluarga contoh yang memiliki usaha menggunakan LPG, jumlah tabung LPG $3 \mathrm{~kg}$ yang digunakan/bulan lebih banyak dibandingkan dengan keluarga contoh yang tidak memiliki usaha menggunakan LPG.

Pengeluaran untuk bahan bakar rumah tangga/bulan. Persentase terbesar keluarga kecil $(51,1 \%)$ mengeluarkan biaya untuk bahan bakar sebesar $\leq \mathrm{Rp} 30.000,00$. Persentase terbesar keluarga besar $(50 \%)$ mengeluarkan biaya untuk bahan bakar sebesar > Rp 90.000,00. Hasil uji korelasi Pearson menunjukkan bahwa besar keluarga memiliki hubungan positif dengan pengeluaran untuk bahan bakar rumah tangga/bulan $(p=0,003 ; r=0,393)$. Hal ini berarti semakin banyak jumlah anggota keluarga maka pengeluaran untuk bahan bakar semakin meningkat. Semakin banyak jumlah anggota keluarga maka kebutuhan akan pangan bertambah dan hal itu berpengaruh terhadap penggunaan bahan bakar.

Persentase terbesar pengeluaran untuk bahan bakar per bulan keluarga yang tidak memiliki usaha menggunakan LPG $(45,6 \%)$ sebesar kurang atau sama dengan Rp 30.000,00 sedangkan pada keluarga contoh yang memiliki usaha (50\%) sebesar lebih atau sama dengan Rp $90.000,00$. Hasil uji korelasi Pearson juga menunjukkan bahwa kepemilikan usaha berhubungan dengan pengeluaran untuk bahan bakar rumah tangga/bulan ( $p=0,000 ; r=0,615)$. Hal ini berarti jika keluarga memiliki usaha yang menggunakan LPG maka pengeluaran untuk bahan bakar semakin meningkat karena penggunaan LPG pun semakin banyak.

Pengeluaran untuk bahan bakar rumah tangga/bulan juga berhubungan dengan waktu habis tabung LPG $(p=0,000 ; r=-0,563)$ dan jumlah tabung yang digunakan $(p=0,000$; $r=0,913$ ). Hal ini berarti semakin cepat waktu habis tabung LPG maka semakin besar biaya yang dikeluarkan. Begitu pula semakin banyak jumlah tabung yang digunakan/bulan maka semakin besar pula pengeluaran untuk bahan bakar rumah tangga.

\section{Faktor-faktor yang Berpengaruh terhadap Perilaku Penggunaan LPG}

Frekuensi Penggunaan LPG. Nilai adjusted $R$ Square $\left(R^{2}\right)$ dalam model regresi frekuensi penggunaan LPG adalah sebesar 0,119 sehingga hanya $11,9 \%$ variabel yang mempengaruhi frekuensi penggunaan LPG dan sisanya dipengaruhi oleh variabelvariabel di luar penelitian sebesar $88,1 \%$. Dari model regresi linier berganda hanya variabel usia ibu rumah tangga $(p=0,050)$ dan pendapatan per kapita $(p=0,056)$ yang mempengaruhi frekuensi penggunaan LPG. Variabel usia pada Tabel 3 memiliki nilai $b=0,079$, artinya setiap kenaikan usia ibu rumah tangga sebanyak satu tahun maka akan meningkatkan frekuensi penggunaan LPG sebanyak 0,079 kali. Hal ini menunjukkan bahwa semakin bertambah usia seseorang, maka frekuensi penggunaan LPG akan bertambah pula. Hal ini diduga ibu rumah tangga yang berusia lebih tua cenderung tidak bekerja sehingga frekuensi penggunaan LPG lebih sering dibandingkan ibu rumah tangga yang berusia muda. Pendapatan per kapita keluarga juga memiliki pengaruh yang nyata terhadap frekuensi penggunaan LPG. Berdasarkan hasil uji regresi, setiap terjadi peningkatan pendapat-

Tabel 3. Faktor-faktor yang mempengaruhi frekuensi penggunaan LPG

\begin{tabular}{|c|c|c|}
\hline \multirow[b]{2}{*}{ Variabel Bebas } & \multicolumn{2}{|c|}{ Frekuensi } \\
\hline & $\begin{array}{l}\text { Koefisien } \\
\text { Regresi (B) }\end{array}$ & $\mathbf{P}$ \\
\hline (Constant) & $-16,171$ & 0,137 \\
\hline Usia ibu rumah tangga (th) & 0,079 & $0,050 *$ \\
\hline $\begin{array}{l}\text { Pendidikan ibu rumah tangga } \\
\text { (th) }\end{array}$ & 0,678 & 0,120 \\
\hline $\begin{array}{l}\text { Kepemilikan usaha } \\
\text { menggunakan gas }\end{array}$ & $-0,848$ & 0,421 \\
\hline Jumlah anggota keluarga (org) & $-0,231$ & 0,442 \\
\hline $\begin{array}{l}\text { Pendapatan } \\
\text { perkapita(Rp/kapita/bulan) }\end{array}$ & $-3,9 E-006$ & $0,056^{*}$ \\
\hline $\begin{array}{l}\text { Jumlah informasi yang } \\
\text { dimiliki(buah) }\end{array}$ & $-0,691$ & 0,506 \\
\hline Pengetahuan tentang LPG & 0,459 & 0,241 \\
\hline Persepsi terhadap LPG & $-0,057$ & 0,717 \\
\hline Sikap terhadap LPG & $-0,238$ & 0,444 \\
\hline Adjusted R Square & \multicolumn{2}{|l|}{0,119} \\
\hline $\mathrm{F}$ & \multicolumn{2}{|l|}{1,025} \\
\hline
\end{tabular}

Ket.: * $=$ nyata pada $p<0,1$ 
penggunaan LPG sebanyak $3,9 \times 10^{-6}$ kali. Hal ini diduga karena semakin bertambahnya pendapatan maka kecenderungan seseorang untuk memilih memakan masakan siap saji semakin besar.

Jumlah tabung LPG 3 kg yang digunakan/bulan. Hasil uji regresi linier berganda pada Tabel 2 menunjukkan bahwa nilai adjusted $R$ Square $\left(R^{2}\right)$ dalam model regresi untuk pengeluaran bahan bakar per bulan adalah sebesar 0,512. Hal ini berarti bahwa beberapa variabel di atas hanya dapat menjelaskan $51,2 \%$ dari faktor yang mempengaruhi pengeluaran untuk bahan bakar per bulan, selebihnya dijelaskan oleh variabel-variabel yang lain di luar model tersebut sebesar $48,8 \%$. Dari model regresi linier berganda hanya variabel kepemilikan usaha yang menggunakan LPG $(p=0,000)$, jumlah anggota keluarga $(p=0,000)$ dan pengetahuan ibu rumah tangga mengenai LPG $(p=0,062)$ yang memiliki pengaruh nyata terhadap pengeluaran untuk LPG per bulan (Tabel 4).

Tabel 4. Faktor-faktor yang mempengaruhi penggunaan jumlah tabung LPG 3 $\mathrm{kg} / \mathrm{bulan}$

\begin{tabular}{|c|c|c|}
\hline \multirow{2}{*}{ Variabel Bebas } & \multicolumn{2}{|c|}{$\begin{array}{c}\text { Penggunaan LPG } 3 \\
\text { kg/bulan }\end{array}$} \\
\hline & $\begin{array}{c}\text { Koefisien } \\
\text { Regresi (B) }\end{array}$ & $\mathbf{P}$ \\
\hline (Constant) & 6,146 & 0,253 \\
\hline Usia ibu rumah tangga (th) & 0,031 & 0,121 \\
\hline $\begin{array}{l}\text { Pendidikan ibu rumah } \\
\text { tangga (th) }\end{array}$ & 0,296 & 0,170 \\
\hline $\begin{array}{l}\text { Kepemilikan usaha } \\
\text { menggunakan gas }\end{array}$ & 3,113 & 0,000 ** \\
\hline $\begin{array}{l}\text { Jumlah anggota keluarga } \\
\text { (org) }\end{array}$ & 0,680 & $0,000^{* *}$ \\
\hline $\begin{array}{l}\text { Pendapatan } \\
\text { perkapita(Rp/kapita/bulan) }\end{array}$ & 1,23E-006 & 0,220 \\
\hline $\begin{array}{l}\text { Jumlah informasi yang } \\
\text { dimiliki(buah) }\end{array}$ & $-0,489$ & 0,343 \\
\hline Pengetahuan & $-0,366$ & $0,062^{*}$ \\
\hline Persepsi & 0,056 & 0,476 \\
\hline Sikap & $-0,169$ & 0,275 \\
\hline Adjusted R Square & \multicolumn{2}{|c|}{0,512} \\
\hline $\mathrm{F}$ & \multicolumn{2}{|c|}{9,977} \\
\hline
\end{tabular}

Keterangan: * $=$ nyata pada $p<0,1$

$$
* *=\text { nyata pada } p<0,01
$$

Variabel kepemilikan usaha yang menggunakan LPG memiliki nilai $b=3,113$ artinya setiap ibu rumah tangga yang memiliki usaha menggunakan LPG maka akan meningkatkan jumlah tabung LPG yang digunakan per bulan sebesar 3,113 kali. Hal ini menunjukkan bahwa ibu rumah tangga yang memiliki usaha menggunakan LPG akan membutuhkan LPG lebih banyak dibandingkan dengan keluarga contoh yang tidak memiliki usaha. Jumlah anggota keluarga juga memiliki pengaruh yang nyata terhadap jumlah tabung LPG $3 \mathrm{~kg}$ yang digunakan dengan nilai $b=0,680$. Berdasarkan hasil uji regresi, setiap terjadi peningkatan jumlah anggota keluarga (besar keluarga) satu orang akan meningkatkan jumlah tabung yang digunakan sebanyak 0,680 kali. Bertambahnya jumlah anggota keluarga akan mempengaruhi jumlah pangan yang dikonsumsi dan ini berkaitan dengan pengolahan pangan tersebut. Selain itu, setiap bertambahnya pengetahuan mengenai LPG maka akan menurunkan jumlah tabung LPG $3 \mathrm{~kg}$ yang digunakan per bulan sebesar 0,366 kali. Hal ini karena ketika seseorang memiliki pengetahuan yang baik mengenai LPG maka akan menggunakan LPG sebaik mungkin yaitu dengan efektif dan efisien.

Pengeluaran untuk LPG. Hasil dari uji regresi linier berganda pada Tabel 5 menunjukkan bahwa nilai adjusted $R$ square $\left(R^{2}\right)$ dalam model regresi untuk pengeluaran untuk bahan bakar/bulan adalah sebesar 0,551. Hal ini berarti bahwa beberapa variabel di atas hanya dapat menjelaskan $55,1 \%$ dari faktor yang mempengaruhi pengeluaran untuk bahan bakar/bulan, selebihnya dijelaskan oleh variabel-variabel yang lain di luar model tersebut sebesar $44,9 \%$. Dari model regresi linier berganda hanya variabel usia ibu rumah tangga $(p=0,055)$, pendidikan $(p=0,080)$ kepemilikan usaha yang menggunakan LPG $(p=0,000)$, jumlah anggota keluarga $(p=0,000)$ dan pengetahuan ibu rumah tangga mengenai bahan bakar $(p=0,053)$ yang memiliki pengaruh nyata terhadap pengeluaran untuk LPG per bulan.

Variabel usia pada Tabel 5 memiliki nilai $b=559,172$, artinya setiap kenaikan usia ibu rumah tangga sebanyak satu tahun maka akan meningkatkan pengeluaran untuk LPG sebanyak 559,172 kali. Variabel kepemilikan usaha yang menggunakan LPG memiliki nilai $b=49660,336$, artinya setiap ibu rumah tangga yang memiliki usaha menggunakan LPG maka akan meningkatkan pengeluaran untuk LPG per bulan sebesar 49660,336 kali. Hal ini menunjukkan bahwa ibu rumah tangga yang memiliki usaha menggunakan LPG akan membutuhkan LPG lebih banyak sehingga pengeluaran untuk bahan bakar pun meningkat. Berdasarkan hasil uji regresi, jumlah anggota keluarga (besar keluarga) juga memiliki pengaruh yang nyata terhadap pengeluaran untuk LPG. Setiap terjadi 
peningkatan jumlah anggota keluarga (besar keluarga) satu orang akan meningkatkan pengeluaran untuk bahan bakar LPG sebanyak 10727,035 kali.

Tabel 5. Faktor-faktor yang mempengaruhi pengeluaran untuk LPG

\begin{tabular}{|c|c|c|}
\hline \multirow{2}{*}{ Variabel Bebas } & \multicolumn{2}{|c|}{$\begin{array}{l}\text { Pengeluaran untuk } \\
\text { LPG }\end{array}$} \\
\hline & $\begin{array}{c}\text { Koefisien } \\
\text { Regresi (B) }\end{array}$ & $\mathbf{P}$ \\
\hline (Constant) & 69225,883 & 0,380 \\
\hline Usia ibu rumah tangga (th) & 559,172 & $0,055^{*}$ \\
\hline $\begin{array}{l}\text { Pendidikan ibu rumah tangga } \\
\text { (th) }\end{array}$ & 5578,873 & $0,080^{*}$ \\
\hline $\begin{array}{l}\text { Kepemilikan usaha } \\
\text { menggunakan gas }\end{array}$ & 49660,336 & $0,000^{* \star}$ \\
\hline $\begin{array}{l}\text { Jumlah anggota keluarga } \\
\text { (org) }\end{array}$ & 10727,035 & $0,000^{\star \star}$ \\
\hline $\begin{array}{l}\text { Pendapatan } \\
\text { perkapita(Rp/kapita/bulan) }\end{array}$ & 0,025 & 0,094 \\
\hline $\begin{array}{l}\text { Jumlah informasi yang } \\
\text { dimiliki(buah) }\end{array}$ & $-2277,073$ & 0,763 \\
\hline Pengetahuan & $-5573,167$ & $0,053^{*}$ \\
\hline Persepsi & 598,205 & 0,603 \\
\hline Sikap & $-2241,272$ & 0,324 \\
\hline Adjusted R Square & 0,551 & \\
\hline $\mathrm{F}$ & 11,496 & \\
\hline
\end{tabular}

Tabel 5 menunjukkan bahwa semakin bertambah pengetahuan mengenai LPG maka akan menurunkan pengeluaran untuk bahan bakar/bulan sebesar 5573,167 kali. Pengetahuan yang baik mengenai LPG baik itu keunggulan maupun penggunaannya akan membuat ibu rumah tangga bijak dalam menggunakan LPG. Pengetahuan yang baik juga akan membuat ibu rumah tangga menggunakan LPG sebagai bahan bakar utama rumah tangga sehingga pengeluaran bahan bakar akan lebih kecil dibandingkan ibu rumah tangga yang menggunakan LPG dan bahan bakar lain secara bergantian.

\section{KESIMPULAN DAN SARAN}

\section{Kesimpulan}

Rata-rata usia istri 38,8 tahun dan usia suami 43,6 tahun. Lebih dari separuh keluarga contoh $(58,7 \%)$ termasuk dalam kelompok keluarga kecil. Persentase terbesar tingkat pendidikan istri $(41,2 \%)$ dan suami $(35,1 \%)$ ialah tamat SD. Hanya $16,3 \%$ istri bekerja umumnya sebagai pedagang sedangkan persentase terbesar suami $(37,8 \%)$ bekerja sebagai buruh. Rata-rata pendapatan/kapita/bulan keluarga sebesar Rp 341.838,14.

Sebagian besar ibu rumah tangga memiliki satu sumber informasi mengenai program konversi BBM dan cara penggunaan LPG yaitu dari penyuluh. Sebesar $72,5 \%$ ibu rumah tangga memiliki persepsi yang cukup baik terhadap LPG, sebagian ibu rumah tangga memiliki tingkat pengetahuan $(77,5 \%)$ dan sikap $(81,2 \%)$ yang baik terhadap LPG

Sebagian besar ibu rumah tangga $(80 \%)$ menggunakan hanya LPG sebagai bahan bakar rumah tangga, 17,5\% menggunakan LPG dan bahan bakar lain sebagai bahan bakar rumah tangga dan sebagian kecil $(2,5 \%)$ menggunakan bahan bakar selain LPG sebagai bahan bakar rumah tangga. LPG umumnya digunakan untuk memasak air, nasi, sayur, dan lauk, separuh ibu rumah tangga (53,7\%) menggunakan peralatan rumah tangga elektronik untuk memasak nasi. Ibu rumah tangga pada umumnya memiliki satu tabung LPG ukuran $3 \mathrm{~kg}$ dengan rata-rata penggunaan untuk 7-14 hari. Rata-rata keluarga contoh menggunakan 3,4 tabung LPG per bulan dengan total pengeluaran untuk bahan bakar per bulan sebesar Rp 54.781,00.

Semakin banyak jumlah anggota keluarga maka waktu habis satu tabung LPG $3 \mathrm{~kg}$ semakin cepat, jumlah tabung yang digunakan semakin banyak dan pengeluaran untuk LPG semakin besar. Selain itu, kepemilikan usaha yang menggunakan LPG juga akan mempercepat waktu habis satu tabung LPG $3 \mathrm{~kg}$, semakin banyak jumlah tabung yang digunakan dan semakin besar pula pengeluaran untuk bahan bakar.

Usia ibu rumah tangga berpengaruh terhadap frekuensi penggunaan bahan bakar dan pengeluaran untuk LPG. Pendapatan per kapita keluarga berpengaruh terhadap frekuensi penggunaan LPG. Kepemilikan usaha yang menggunakan LPG dan jumlah anggota keluarga berpengaruh terhadap penggunaan jumlah tabung LPG $3 \mathrm{~kg} / \mathrm{bulan}$ dan pengeluaran untuk LPG/bulan. Pengetahuan ibu rumah tangga mengenai LPG berpengaruh terhadap penggunaan jumlah tabung LPG $3 \mathrm{~kg} / \mathrm{bulan}$ dan pengeluaran untuk LPG/bulan.

\section{Saran}

Masyarakat sudah beradaptasi dengan perubahan penggunaan bahan bakar tetapi masih ada ibu rumah tangga yang tidak bisa memasang sendiri LPG tanpa bantuan orang lain dengan alasan masih ada rasa khawatir. Hal ini menunjukkan bahwa sosialisasi keamanan dan efisiensi penggunaan LPG dari pihak terkait kepada masyarakat untuk 
menciptakan rasa lebih aman dalam menggunakan LPG serta penyediaan jasa perbaikan kompor gas masih diperlukan.

Selain itu perlu adanya program untuk menumbuhkan kesadaran masyarakat dalam mengatur keuangan rumah tangga. Diharapkan ada penelitian lanjutan yang membandingkan pengambilan keputusan dan alokasi pengeluaran pengguna bahan bakar pada rumah tangga tidak hanya pengguna minyak tanah, kayu bakar, dan LPG tetapi juga pengguna bahan bakar alternatif.

\section{DAFTAR PUSTAKA}

Amiruddin. 2009. Analisis Pengetahuan, Persepsi dan Sikap Konsumen Terhadap Produk LPG Pertamina Kemasan $3 \mathrm{~kg}$ (Studi Kasus di Desa Leuwiliang, Kecamatan Leuwiliang, Kabupaten Bogor, Jawa Barat) [Tesis]. Bogor: Sekolah Pascasarjana Institut Pertanian Bogor.

Anonim. 2007. Program Konversi. http://www.Pertamina.com. [29 Maret 2009].

[BPS] Biro Pusat Statistik. 2009. Pengeluaran Pendapatan per Kapita Sebulan menurut Kabupaten/Kota Kelompok Barang di Jawa Barat. Badan Pusat Statistik. Bandung: BPS Propinsi Jawa Barat. http://jabar.bps.go.id [5 Desember 2009].

Departemen ESDM. 2007. Program Pengalihan Minyak Tanah ke LPG Dalam Rangka Pengurangan Subsidi

${ }^{*}$ Korespondensi :

Email :diahkp@yahoo.com
BBM. $\quad$ http://www.migas.esdm.go.id. Jakarta [22 Juli 2009].

Engel JF, Blackwell RD, Miniard PW. 1994. Perilaku Konsumen Jilid I. Edisi ke-6. Budiyanto FX, Penerjemah. Jakarta: Binarupa Aksara.

Ilyas AZ, Sudarnika E. 2002. Hubungan Karakteristik Peternakan Sapi Perah Dengan Sikap dan Perilaku Aktual dalam Pengolahan Limbah Peternakan [Laporan Penelitian]. Bogor: Fakultas Peternakan Institut Pertanian Bogor.

Latifah EW. 2010. Analisis Persepsi, Sikap, dan Strategi Koping Keluarga Miskin terkait Program Konversi Minyak Tanah ke LPG di Kota Bogor [Skripsi]. Bogor: Fakultas Ekologi Manusia, Institut Pertanian Bogor.

Okturna. 2004. Persepsi Masyarakat terhadap Jajanan Sayuran di Kawasan KKP IPB Baranang Siang II. [Skripsi]. Bogor: Fakultas Pertanian, Institut Pertanian Bogor.

Satriya E. 2007. Menyoal Konversi Minyak Tanah ke Bahan Bakar Gas. http://kolom.pacific.net.id/ind/artikel. [31 Oktober 2009].

Sumarwan U. 2004. Perilaku Konsumen: Teori dan Penerapannya dalam Pemasaran. Bogor: Ghalia. 2006. Peran IImu Konsumen dalam Peningkatan Kesejahteraan Melalui Pemenuhan Hak Atas Informasi. Bogor: Fakultas Ekologi Manusia, Institut Pertanian Bogor. 